\title{
The Effect of Biological, Social, Economic, and Nutritional Factors on Low Birth Weight: A New Path Analysis Evidence from Madiun Hospital, East Java, Indonesia
}

\author{
Novi Paramitasari MS1), Harsono Salimo²), Bhisma Murti3) \\ 1)Masters Program in Public Health, Universitas Sebelas Maret \\ 2)Department of Pediatrics, Dr. Moewardi Hospital, Surakarta \\ 3)Department of Public Health, Faculty of Medicine, Universitas Sebelas Maret
}

\begin{abstract}
Background: Low birth weight (LBW) remains a major cause of death and illness in infants. This study aimed to analyze the effects of biological, social, economic, and nutritional factors on LBW at Madiun General Hospital, East Java.

Subjects and Method: This was an analytic observational study with a case-control design. The study was conducted at Madiun General Hospital, East Java, from January to December 2017. A sample of 200 newborn babies were selected for this study using fixed disease sampling, consisting of 50 babies with low birth weight and 150 control infants with normal birth weight. The dependent variable was birth weight. The independent variables were maternal age, education, parity, maternal nutritional status, maternal employment, family income, anemia, and birth space. Clinical data were taken from medical record. The data of other variables were collected by questionnaire. Path analysis was employed for data analysis.

Results: The risk of LBW increased with anemia $(b=1.09$; CI $95 \%=0.27$ to $1.91 ; p=0.009)$, multiparity $(\mathrm{b}=1.73$; CI 95\% $=0.28$ to $2.06 ; \mathrm{p}=0.010)$, and age $<20$ or $>35$ years $(\mathrm{b}=1.41$; CI $95 \%=0.24$ to $2.57 ; \mathrm{p}=0.018)$. The risk of LBW decreased with good maternal nutritional status $(b=-1.49$; CI $95 \%=-2.32$ to $-0.65 ; p<0,001)$, maternal education $\geq$ high school $(b=-1.05 ;$ CI $95 \%=-1.88$ to $-0.21 ; \mathrm{p}=0.014)$, and wide birth space $(\mathrm{b}=-1.06$; CI $95 \%=-2.24$ to $0.11 \mathrm{p}=0.076)$. Maternal employment and family income had indirect effect on the risk of LBW.

Conclusion: The risk of LBW is affected by anemia, parity, maternal age $<20$ years and $\geq 35$ years, poor maternal nutritional status, low maternal education, and narrow birth space.
\end{abstract}

Keywords: low birth weight, biological factor, social factor, economic factor

\section{Correspondence:}

Novi Paramitasari MS, Masters Program in Public Health, Universitas Sebelas Maret. Jl. Ir. Sutami No.36 A, 57126, Surakarta, Central Java. Email: noviparamitasarims27@gmail.com

\section{BACKGROUND}

Infant mortality is one of the priority problems in developing countries including Indonesia. Infant mortality not only reflects the health of the baby but also the welfare of society as a whole. As known, infant mortality is also one indicator of health status in Indonesia. Infant Mortality Rate (IMR) only slightly decreases each year (Lamichhane et al 2017, Khadka et al 2015, Ministry of Health, 2015).

The cause of Low Birth Weight (LBW) is also influenced by several factors that in- fluence the incidence of LBW ie factors related to mother like, mother age, age of pregnant, parity, body weight and height body mass index, BMI, routine pregnancy screening (ANC), regular drinking of tablets blood adding/ FE tablets, nutritional status during pregnancy, anemia in pregnant women, alcohol and smoking habits, diseases during pregnancy, distance of pregnancy, history of abortion. Fetal factors include multiple pregnancies, congenital abnormalities, infant factors such as gender and race. Environmental factors include mater- 
nal education and knowledge, achievement, socioeconomic status (Mitao et al., 2016; Baskhar et al., 2015; Feresu et al., 2015).

According to the report of the Health Office of East Java Province (2013), it is known that the number of babies born with LBW reached $3.32 \%$ obtained from the data on the percentage of births of 19,712 babies of 594,461 newborns weighed. The highest LBW rate was in Madiun City of 9.66\% and the lowest was in Bangkalan District at 1.25\%. From the data of 2015 Madiun health office, the incidence of LBW in Madiun is 140 cases of LBW with the percentage of $5.56 \%$ decreased compared to that of 2014 which is 168 cases with the percentage $(6.00 \%)$ of babies with LBW. This is mostly caused by interference or comorbidities in pregnant women such as anemia, chronic energy deficiency, hypertension, preeclampsia/ eclampsia, gemeli, infection, congenital abnormalities and others so that the baby is born aterm or not yet term born birth Low Birth Attendance.

Infants with LBW are among the causes of neonatal death, in addition to Birth Trauma, Asphyxia, Infection, Tetanus Neonaorum (TN), Congenital Abnormalities and Others. Neonatal mortality caused by LBW reached $38.03 \%$ and this figure is the highest compared to other causes (Health Office, East Java, 2013).

This study aimed to analyze the effects of biological, social, economical factors and the nutritional status of the pregnant women on the low birthweight in Madiun hospital, East Java.

\footnotetext{
SUBJECTS AND METHOD

1. Study design

This was an analytic observational study with a case control design. The study was conducted at Madiun hospital, East Java, from January to December 2017.
}

\section{Population and sample}

The target population in the study was all infants born Madiun city hospital in January to December 2017 period. A sample of 200 infants was selected by fixed disease sampling including 50 infants with low birthweight and of 150 infants with normal birthweight.

The inclusion criteria included infant birth weight $(<2500$ gram) born in Madiun city hospital during the study period, normal birth weight (2500-400o gram), mothers with a history of normal pregnancy, mothers willing to be respondents, have maternal and child monis book or pregnancy check book, residing in the area of Madiun City. The exclusion criteria consisted of a born-again baby, a mother who has a history of pre-eclampsia, eclampsia, diabetes mellitus and twins, a mother who gave birth to a baby weighing more than 4000 grams, a mother who moved outside the Madiun City area.

\section{Study variables}

The independent variables were maternal education, maternal occupation, family income, maternal age, parity, birth spacing, maternal nutritional status during pregnancy, and anemia in pregnancy. The dependent variable was low birthweight (LBW).

\section{Operational definition of variables}

Birth weight was defined as infant body weight at birth measured in gram unit. The data were taken from medical record. The measurement scale was continuous, but for the purpose of data analysis, it was transformed into dichotomous coded o for

Maternal education was defined as the highest formal education status of mothers. The data were collected by questionnaire. The measurement scale was categorical.

Maternal occupation was defined as a job inside and outside the home that can support the family income. The data were 
Journal of Maternal and Child Health (2018), 3(3): 166-175

https://doi.org/10.26911/thejmch.2018.03.03.01

collected by questionnaire. The measurement scale was categorical.

Family income was defined as the amount of family income received in a month as an economic source. Income can be measured by minimum regional wage. The measurement scale was continuous.

Maternal age was defined as the age at the time of delivery. The data were collected by medical record. The measurement scale was continuous.

Parity was defined as the number of live-born children. The data were collected by questionnaires. The measurement scale was continuous.

Birth spacing was defined as the period of time between a pregnancy with subsequent pregnancies. The data were collected by questionnaires. The measurement scale was continuous.

Data on maternal nutritional status during pregnancy were measured by Middle Upper Arm Circumference (MUAC) size using MUAC tape. The data were taken from maternal and child health monitoring book. The measurement scale was continuous.

Anemia in pregnancy was defined as a maternal hemoglobin levels during pregnancy less than $11 \mathrm{~g} / \mathrm{dl}$ from the first trimester to the $3^{\text {rd }}$ trimester of pregnancy. The data were taken from maternal and child monitoring book.

\section{Data analysis}

The data analysis was conducted using path analysis to know the influence of direct and indirect variable. Path analysis steps including model specification, model identification, model fit, parameter estimate, and model re-spesification.

\section{RESULTS \\ 1. The Characteristics of Subjects \\ Univariate analysis was conducted to ex- plain and describe the characteristics of each research variable based on primary and secondary data.}

Table 1. Subject Characteristics

\begin{tabular}{|c|c|c|c|}
\hline The Characteristics of Subjects & Criteria & Frequency & (\%) \\
\hline \multirow[t]{2}{*}{ Maternal Age } & 20-35 years old & 155 & 77.5 \\
\hline & $\begin{array}{l}<20 \text { atau }>35 \\
\text { years old }\end{array}$ & 45 & 22.5 \\
\hline \multirow[t]{2}{*}{ Parity } & 1 or $\geq 3$ & 121 & 60.5 \\
\hline & $2-3$ & 79 & 39.5 \\
\hline \multirow[t]{2}{*}{ Birth spacing } & $<2$ years & 22 & 11 \\
\hline & $\geq 2$ years & 178 & 89 \\
\hline \multirow[t]{2}{*}{ Maternal education } & $<$ SHS & 54 & 27 \\
\hline & $\geq$ SHS & 146 & 73 \\
\hline \multirow[t]{2}{*}{ Maternal occupation } & Working at home & 142 & 71 \\
\hline & Working outside & 58 & 29 \\
\hline \multirow[t]{2}{*}{ Family Income } & $<1,394,000$ & 115 & 57.5 \\
\hline & $\geq 1,394,000$ & 85 & 42.5 \\
\hline \multirow[t]{2}{*}{ Maternal nutritional status (MUAC) } & $<23.5 \mathrm{~cm}$ & 46 & 23 \\
\hline & $\geq 23.5 \mathrm{~cm}$ & 154 & 77 \\
\hline \multirow[t]{2}{*}{ Pregnancy anemia } & $<11 \mathrm{~g} / \mathrm{dl}$ & 59 & 29.5 \\
\hline & $\geq 11 \mathrm{~g} / \mathrm{dl}$ & 141 & 70.5 \\
\hline \multirow[t]{2}{*}{ Birth weight } & $<2500$ gram & 50 & 25 \\
\hline & $\geq 2500$ gram & 150 & 75 \\
\hline
\end{tabular}

\section{Path Analysis}

The results of path analysis by STATA 13 are the following variables:
The number of observed variables were 9, endogenous variables were 5 , and exogenous variables were 4 , so that the degree 
of freedom (df) was 28 (over-identified). analysis can be done.

Degree of freedom $>1$ showed that path

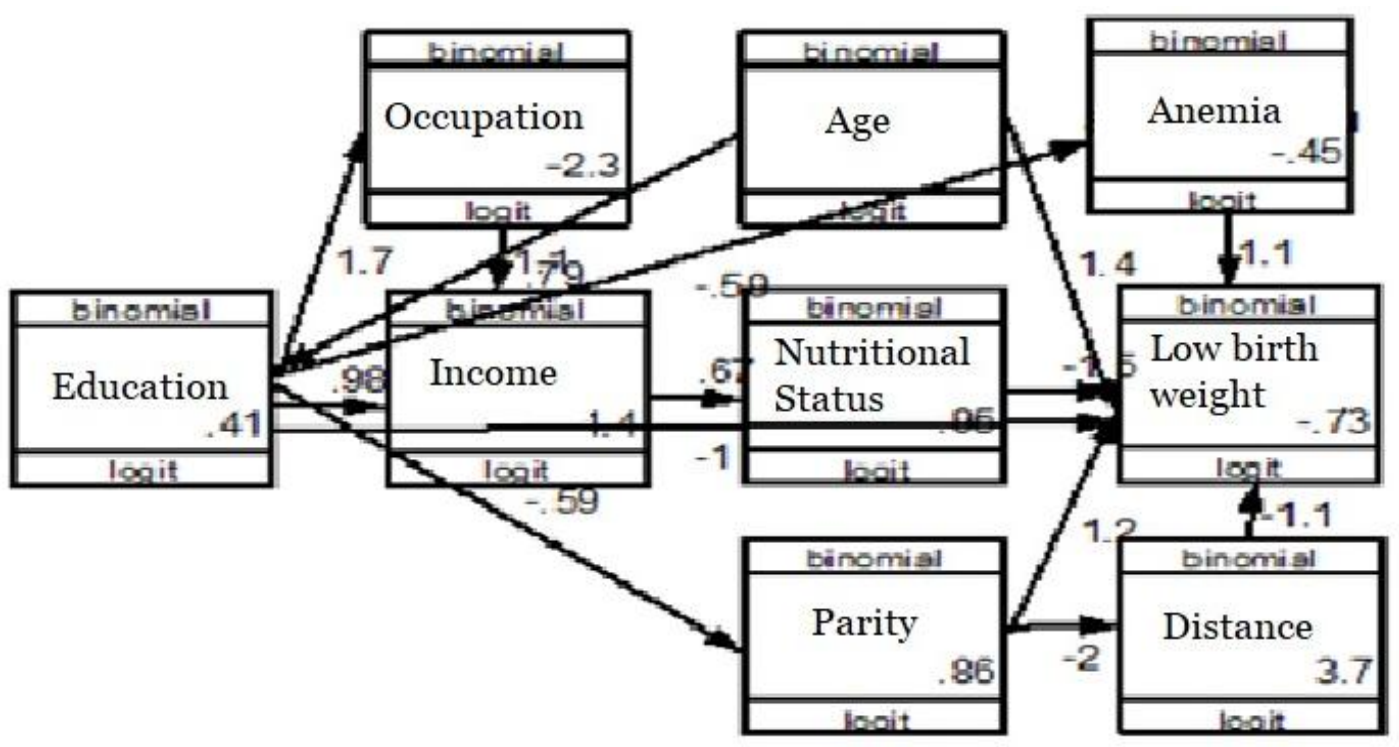

Figure 1. Structural model with estimate

Table 2. The results of path analysis on the association between biological, social, economic, and maternal gestational nutritional status, and LBW in Madiun Hospital

\begin{tabular}{|c|c|c|c|c|c|c|}
\hline \multirow[b]{2}{*}{$\begin{array}{c}\text { Dependent } \\
\text { variable }\end{array}$} & \multirow{2}{*}{\multicolumn{2}{|c|}{ Independent variable }} & \multirow[b]{2}{*}{$\mathbf{b}$} & \multicolumn{2}{|c|}{$95 \%$ CI } & \multirow[b]{2}{*}{$\mathbf{p}$} \\
\hline & & & & $\begin{array}{l}\text { Lower } \\
\text { Limit }\end{array}$ & $\begin{array}{l}\text { Upper } \\
\text { Limit }\end{array}$ & \\
\hline \multicolumn{7}{|l|}{ Direct Effect } \\
\hline Low birthweight & $\leftarrow$ & Nutritional status & -1.49 & -2.32 & -0.65 & $<0.001$ \\
\hline Low birthweight & $\leftarrow$ & Maternal education & -1.05 & -1.88 & -0.21 & 0.014 \\
\hline Low birthweight & $\leftarrow$ & Anemia & 1.09 & 0.27 & 1.91 & 0.009 \\
\hline Low birthweight & $\leftarrow$ & Parity & 1.17 & 0.28 & 2.07 & 0.010 \\
\hline Low birthweight & $\leftarrow$ & Maternal age & 1.41 & 0.24 & 2.57 & 0.018 \\
\hline Low birthweight & $\leftarrow$ & Pregnancy distance & -1.07 & -2.24 & 0.11 & 0.076 \\
\hline \multicolumn{7}{|l|}{ Indirect Effect } \\
\hline Nutritional status & $\leftarrow$ & Income & 0.67 & -0.03 & 1.37 & 0.062 \\
\hline \multirow[t]{2}{*}{ Income } & & Maternal education & 0.98 & 0.24 & 1.73 & 0.010 \\
\hline & & Maternal occupation & 1.14 & 0.48 & 1.80 & 0.001 \\
\hline Anemia & $\leftarrow$ & Maternal education & -0.59 & -1.25 & 0.07 & 0.079 \\
\hline Occupation & $\leftarrow$ & Maternal education & 1.72 & 0.74 & 2.70 & 0.001 \\
\hline Parity & $\leftarrow$ & Maternal education & -0.59 & -1.26 & 0.08 & 0.085 \\
\hline Distance & $\leftarrow$ & Parity & -2.03 & -3.52 & -0.55 & 0.007 \\
\hline Education & $\leftarrow$ & Maternal Age & 0.79 & 0.09 & 1.49 & 0.028 \\
\hline \multicolumn{7}{|c|}{$\mathrm{N}$ observation $=200$} \\
\hline \multicolumn{7}{|c|}{ Log likelihood= -856.57} \\
\hline \multicolumn{7}{|l|}{$\mathrm{AIC}=1757$} \\
\hline \multicolumn{7}{|l|}{$\mathrm{BIC}=1829$} \\
\hline
\end{tabular}

There was a negative association between nutritional status and LBW and it was statistically significant. Children with good nutritional status reduced the risk of
LBW (b=-1.49; 95\% CI $=-2.32$ to $-0.65 ; \mathrm{p}$ $<0.001)$.

There was a negative association between maternal education and LBW. 
Maternal education $\geq$ Senior high school reduced the risk of LBW $(b=-1.05 ; 95 \%$ $\mathrm{CI}=-1.88$ to $-0.21 ; \mathrm{p}=0.014$ ).

There was a positive association between maternal anemia during pregnancy and LBW. Pregnant mother with anemia increased the risk of LBW (b= 1.09; $95 \% \mathrm{CI}=0.27$ to $1.91 ; \mathrm{p}=0.009$ ).

There was a positive association between parity and LBW. Parity >3 increased the risk of LBW $(b=1.17 ; 95 \%$ $\mathrm{CI}=0.28$ to $2.07 ; \mathrm{p}=0.010$ ).

There was a positive association between maternal age and LBW. Maternal age at pregnancy $<20$ or $>35$ years increased the risk of LBW $(b=1.41 ; 95 \%$ $\mathrm{CI}=0.24$ to $2.57 ; \mathrm{p}=0.018$ ).

There was a negative effect between birth spacing and LBW. Birth spacing <2 year increased the risk of LBW $(b=1.067$; $95 \% \mathrm{CI}=-2.24$ to $0.11 ; \mathrm{p}=0.076$ ).

There was a positive association between family income and maternal MUAC during pregnancy. Family income $\geq$ minimum wage improved maternal MUAC $(b=0.67 ; 95 \% \mathrm{CI}=-0.03$ to 1.37 ; $\mathrm{p}=0.062$ ).

There was a positive association between maternal education and family income. Maternal education $\geq$ Senior high school increased the likelihood of family income $(b=0.98 ; 95 \% \mathrm{CI}=0.24$ to 1.73 ; $\mathrm{p}=$ 0.010).

There was a positive association between maternal occupation and family income. Mother who works outside the house increased the likelihood of family income $(b=1.14 ; 95 \% \mathrm{CI}=0.48$ to $1.80 ; \mathrm{p}$ $=0.001$ ).

There was a negative association between maternal education and maternal anemia during pregnancy. Maternal education $\geq$ Senior high school reduced the risk of anemia in mother during pregnancy $(b=-0.59 ; 95 \% \mathrm{CI}=-1.25$ to 0.07 ; $\mathrm{p}=0.079)$.
There was a positive association between maternal education and family income. Maternal education $\geq$ Senior high school increased family income $(b=0.98$; 95\% $\mathrm{CI}=0.24$ to $1.73 ; \mathrm{p}=0.010$ ).

There was a negative association between maternal education and parity. Maternal education $\geq$ Senior high school lowered parity $(b=-0.59 ; 95 \% \mathrm{CI}=-1.26$ to o.08; $\mathrm{p}=0.085$ ).

There was a negative association between parity and birth spacing. Parity $>3$ lowered birth spacing $(b=-2.03 ; 95 \%$ $\mathrm{CI}=-3.52$ to $-0.55 ; \mathrm{p}=0.007$ ).

There was a positive association between maternal age during pregnancy and maternal education. Reproductive maternal age increased maternal education $(b=0.79 ; 95 \% \mathrm{CI}=0.09$ to 1.49 ; $\mathrm{p}=0.028)$.

\section{The effect of maternal nutritional status during pregnancy and LBW}

This study showed that there was a direct effect between maternal MUAC and LBW. Maternal MUAC $\geq 23.5 \mathrm{~cm}$ reduced the risk of LBW. The assessment of pregnant maternal nutritional status could be done by biochemistry and and anthropometric measurements (Ministry of Health RI, 2012).

Maternal nutritional status in this study was measured by maternal MUAC) (Proverawati, 2009). MUAC was the upper arm of the tricep section. MUAC was used to estimate the thickness of fat under the skin (Almatsier, 2011). The MUAC measurements were quite representative, in which the MUAC size of pregnant women was closely related to maternal BMI. MUAC showed the nutritional status of pregnant women where $<23.5 \mathrm{~cm}$ was belong to malnutrition groups (Ministry of Health RI, 2012). 
Nutrition was one of the main determinants of the quality of Human Resources (HR). Nutritional disorders in early life would affect the quality of subsequent life (Ginsburg et al, 2015).

\section{The effect of maternal education and LBW}

This study showed that there was a direct effect between maternal education and LBW. Maternal education $\geq$ Senior high school reduced the risk of LBW.

High education would enable the mothers to obtain sufficient information in terms of the treatment during pregnancy and infant care and also nutritional fulfillment. Maternal education was an intermediary factor causing lack of nutritional status in pregnant women and resulting in low birth weight, premature birth, and neonatal mortality. Education can change a person's way of thinking, the higher the education, the more critical in responsing to a health problem, easy to receive information, and the higher the prevention and treatment of infants (Bhaskar, 2015; Friedman, 2010).

\section{The effect of maternal anemia at pregnancy and LBW}

This study showed that there was a direct effect between maternal anemia at pregnancy and LBW. Maternal anemia at pregnancy increased the risk of LBW.

The effects of anemia in pregnancy including the risk of LBW, previa placenta, eclampsia, preterm premature rupture of membranes (PPROM), miscarriage, prolonged labor, antepartum bleeding, premature birth, even neonatal death and complications that can occur in neonates, which were premature, low apgar score, and fetal distress (Alam, 2012; Soetjiningsih, 2013, Lalage, 2013; Mansjoer et al, 2008; WHO, 2015).

\section{The effect of parity and LBW}

This study showed that there was a direct effect between parity and LBW. Parity 1 or $>3$ increased the risk of LBW.

Parity turned out to be a high risk at prematurity, Intrauterine Growth Restriction (IUGR) or small for gestation, LBW, and neonatal mortality. This was due to an incomplete maternal gynecological condition and malnutrition which relatively be the cause of the high risk. First parity can lead to LBW because of the lack of maternal information and experience so that the maternal knowledge to fulfill the nutrition and pregnancy care was weak. Parity $>3$ can cause LBW because it would generally have complications and disorders in pregnancy (Tristiyanti, 2006). Parity 2-3 was the safest condition for pregnancy and childbirth during reproductive period, because in that condition, the uterine wall has not changed much (Varney, 2010).

This study showed that there was an indirect effect between parity and LBW through birth spacing. Parity 2 or 3 decreased the risk of LBW than parity 1 or $>3$.

This study was consistent with a study by Lamichhane et al. (2017); Khadka et al. (2015), which reported that infant who were born less than 24 months or 2 years have higher risk of mortality compared to babies born over 24 months. Infant mortality was 2 times risky with shorter birth interval (less than 2 years) most likely born to third and fourth child which was very risky to experience infant mortality.

\section{The effect of maternal age at preg- nancy and LBW}

This study showed that there was a direct effect between maternal age at pregnancy and LBW. Maternal age at pregnancy $<20$ or $>35$ years old increased the risk of LBW. 
Journal of Maternal and Child Health (2018), 3(3): 166-175

https://doi.org/10.26911/thejmch.2018.03.03.01

Women reproductive age was 20-35 years old. Maternal mortality occurred at the age of $<20$ or $>35$ years old were $2-5$ times higher than women with reproductive age (Prawiroharjo, 2012). According to Kozuki et al. (2013), parity and maternal age increase the risk of neonatal death, such as IUGR, LBW, and prematurity. Young mothers increased the risk by 2 times of low birth weight in infants (Sharma, 2015). Maternal age $<20$ or $\geq 35$ years old was directly related to low birth weight of the baby (Bhaskhar et al, 2015; Gebregsabiherher et al, 2017; Shrestha et al., 2016).

This study showed that there was an indirect effect between maternal age at pregnancy and LBW through maternal education. Maternal age at pregnancy $<20$ or $>35$ years old increased the risk of LBW than pregnant mothers with reproductive age(20-35 years old).

Mothers who give birth at mature age have better knowledge about pregnancy and childbirth, and greater responsibility in caring for their baby (Singh, 2013). Maternal age $<20$ years old or $\geq 35$ years old was directly related to low birth weight (Bhaskhar et al., 2015; Gebregsabiherher et al., 2017; Shrestha et al., 2016).

\section{The effect of birth spacing and LBW}

This study showed that there was a direct effect between birth spacing and LBW. Birth spacing $>2$ year reduced the risk of LBW.

Statistically, short birth spacing lead to premature labor, LBW, small infant births according to gestational age, and infant mortality (Perin and Walker, 2015; Kozuki et al, 2013). Short pregnancy gap lead to an increased risk of fetal growth disorders that may result in (LBW, premature birth, and small size of pregnancy resulting in infant mortality (CondeAgudelo, 2006).

\section{The effect of family income and LBW}

This study showed that there was an indirect effect between family income and LBW through maternal nutritional status. Family income $\geq$ minimum regional wage increased maternal MUAC during pregnancy.

A pregnant woman with a low economic level family caused herself to be unable to fulfill the nutritional needs during pregnancy. Therefore, it would make a negative impact on pregnancy. Otherwise, women with a high level of economy would fulfill the nutritional needs during pregnancy and can easily access the health facilities (Aisyan, 2011).

\section{The effect of maternal education and $L B W$}

This study showed that there was an indirect effect between maternal education and LBW through family income. Maternal education $\geq$ senior high school increased family income.

Mother with higher education ( $\geq$ senior high school) was more likely to work outside the house than mother with low education (<senior high school). Maternal education is important for the sustainability of the infants life because it would increase the socioeconomic status that affected the survival of infants in the neonatal period (Ankiyemi et al, 2015).

This study also showed that there was an indirect effect between maternal education on the incidence of LBW through anemia in pregnancy. Maternal education $\geq$ Senior high school reduced the risk maternal anemia during pregnancy.

Maternal education has an indirect relationship with the children mortality. Education was an intermediary factor causing the lack of nutritional status in 
pregnant women resulting in low birth weight, premature birth, and neonatal mortality. Mothers with high level of education allow them to obtain sufficient information in terms of care during pregnancy and infant care and also nutritional fulfillment (Bhaskar 2015).

This study showed that there was an indirect effect between maternal education and LBW through maternal occupation. Maternal education $\geq$ Senior high school increased the likelihood of mother working outside the house.

Maternal education was very important for the survival of infants, with high maternal education, it would improve the socioeconomic status that has been shown to affect the survival of infants in the neonatal period (Ankiyemi et al, 2015).

This study showed that there was an indirect effect between maternal education and LBW through parity. High maternal education reduced parity.

Mothers with a high education enabled them to obtain sufficient information in terms of care during pregnancy and infant care and also nutritional fulfilllment. Maternal education was an intermediary factor which lead to lack of nutritional status in pregnant women and resulting in low birth weight, premature birth, and neonatal mortality. Education can change a person's way of thinking, the higher the education, the more critical in responsing the health problem, it was easy to receive information and the higher the prevention and treatment of infants and toddlers (Bhaskar, 2015; Friedman, 2010; SDKI, 2012).

Parity in mothers was closely related to the incidence of LBW. 1 or $>3$ parity was a risky parity for pregnancy and childbirth. Parity 1 can cause LBW because of the lack of information and experience so that the maternal knowledge to fulfill the nutrition and pregnancy care was poor.
Parity $>3$ can lead to LBW because it would generally have complications and disorders in pregnancy (Tristiyanti, 2006). 2-3 parity was the safest condition for pregnancy and childbirth during reproductive period, because in that condition the uterine wall has not changed much (Varney, 2010). A study done by Sharma (2008) showed that mothers who had 2-3 parities decreased the incidence of LBW by 2.6 times than mothers who had 1 parity.

\section{The effect of maternal occupation and LBW}

This study showed that there was an indirect effect between maternal occupation and LBW. The results of the analysis in this study indicated that infants born from mother who work outside the house would increase the risk of LBW than infants born from mothers who work in the house.

Mother who works outside the house increased family income. High family income may help the mothers to access health services during pregnancy easily and fulfill maternal nutritional status during pregnancy (Malqvist et al., 2011; Titaley et al., 2008).

\section{REFERENCES}

$\overline{\text { Aisyan N, Siti N, Yuniar W (2011). Hu- }}$ bungan Antara Status Sosial ekonomi Keluarga Dengan Kematian Perinatal di Wilayah Kerja Puskesmas Baamang Unit I Sampit Kalimantan Tengah Januari-April 2010. Jurnal Kesehatan Masyarakat 5(1): 1-67.

Alam KD (2012). Warning! Ibu Hamil Kenali Penyakit dan Gangguan yang Biasa Terjadi pada Ibu Hamil. Surakarta: Ziyad Visi Media. ISBN 9789298-53-6.

Almatsier S (2011). Gizi Seimbang Dalam Daur Kehidupan. Jakarta: Gramedia Pustaka Utama. 
Ankiyemi JO, Bamgboge EA, Ayeni O. (2015). Trends In Neonatal Mortality In Nigeria And Effects Of BioDemographic And Maternal Characteristics.BMC Pediatric, 15, 36.

Bhaskar KR, Deo KK, Neupane U, Bhaskar CS, Yadav KB, Pokharel PH, Pokharel KP (2015). A Case Control Study on Risk Factors Associated with Low Birth Weight Babies in Eastern Nepal. Hindawi Publishing Corporation International Journal of Pediatrics. http://dx.doi.org/10.11$55 / 2015 / 807373$.

Conde-Agudelo A (2006). Birth Spasing And Risk Of Adserve Perinatal Outcomes. Jama: The Journal Of The American Medical Association. 295(15): 1809-1823.

Departemen Kesehatan Republik Indonesia. (2015). Profil Kesehatan Indonesia Tahun 2014. Jakarta: Departemen Kesehatan Republik Indonesia.

Dinas Kesehatan Jawa Timur. (2013). Profil Kesehatan Provinsi Jawa Timur Tahun 2012. Surabaya.

Feresu SA, Harlow SD, Woelk GB. (2015). Risk Factors for Low Birthweight in Zimbabwean Women: A Secondary Data Analysis. PLOS ONE 10(6): e0129705. doi:10.1371/journal.pone.0129705.

Friedman EM, Herd P (2010). Income, Education, and Inflammation: Differential Associations in a National Probability Sample (The MIDUS Study). Psychosomatic medicine. 72(3): 290-300. doi:10.1097/PSY.obo13e3181cfe4c2.

Gebregzabiherher Y, Haftu A, Weldemariam S, Gebrehiwet H. The Prevalence and Risk Factors for Low Birth Weight among Term Newborns in Adwa General Hospital, Northern Ethiopia. Obstetrics and Gynecology International.
Ginsburg A, Izadnegahdar R, Berkley JA, Walson JR, Rollin N, Klugman KP (2015). Undernutrition And BBLR Mortality. The Lancet Global Health, 3(12): 735-736.

Khadka KB, Lieberman LS, Giedraitis V, Bhatta L, Pandey G. (2015). The socio-economic determinants of infant mortality in Nepal: analysis of Nepal Demographic Health Survey, 2011. BMC Pediatrics. 2015; 15:152. doi: 10.1186/s12887-015-0468-7.

Kozuki N, Lee CCA, Silveira FM, Sania A, Vogel PJ, Adair L, Barros F, Caulfield EL, Christian P, Fawzi W, Humphrey J, Huybregts L, Mongkolchati A, Ntozini R, Osrin D, Roberfroid D, Tielsch J, Vaidya A, Black ER, Katz J, and Child Health Epidemiology Reference Group (CHERG) Small-for-GestationalAge-Preterm Birth Working Group. The associations of parity and maternal age with small-for-gestational-age, preterm, and neonatal and infant mortality: a meta-analysis. BMC Public Health, 13(3): S2. https://doi.org/10.1186/1471-2458-13-S3S2.

Lalage Z (2013). Menghadapi Kehamilan Berisiko Tinggi. Klaten: Abata Press. ISBN 978-602-7558-59-5.

Lamichhane R, Zhao Y, Paudel S, Adewuyi EO (2017). Factors associated with infant mortality in Nepal: a comparative analysis of Nepal demographic and health surveys (NDHS) 2006 and 2011. BMC Public Health. 17:53. doi:10.1186/s12889-016-3922-z.

Malqvist M (2011). Neonatal mortality: An Invisible And Marginalised Trauma. Global health action.

Mansjoer A (2008). Kapita Selekta Kedokteran, Jakarta: Media Acsulapius. Manuaba. 2012. Ilmu Kebidanan atau Penyakit Kandungan Dan KB 
Untuk Pendidikan Bidan, Edisi 2. Jakarta: EGC.

Mitao M, Philemon R, Obure J, Mmbaga TB, Msuya S, Mahande JM. (2016). Risk factors and adverse perinatal outcome associated with low birth weight in Northern Tanzania: a registry-based retrospective cohort study. Asian Pacific Journal of Reproduction http://dx.doi.org/10.1016/j.apjr.2015.12.014.

Perin J, Walker N (2015). Potential confounding in the association between short birth intervals and increased neonatal, infant, and child mortality. Global Health Action, 8 (1): 29724. DOI: 10.3402/gha.v8.29724.

Prawirohardjo S (2012). Ilmu Kandungan. Edisi III. Jakarta: PT. Bina Pustaka Sarwono Prawirohardjo.

Proverawati A, Ismawati C. (2010). Berat Bayi Lahir Rendah. Yogyakarta: Nuha Medika.

Sharma SR, Giri S, Timalsina U, Bhandari SS, Basyal B, Wagle K, \& Shrestha L. (2015). Low Birth Weight at Term and Its Determinants in a Tertiary Hospital of Nepal: A Case-Control Study. PLoS ONE, 10(4), e0123962. http://doi.org/10.1371/journalpone.0123962
Shrestha M, Gupta SK, Sarmah BK, Baidya M (2016). Socio Economic and Maternal Reproductive Factors Affecting Low Birth Weight Babies in Central Nepal. Journal Nepal Paediatric Soc. 36(3).

Soetjiningsih, Ranuh G. (2013). Tumbuh Kembang Anak. Jakarta: EGC. ISBN 978-979-044-468-8.

Titaley C, Michael JD, Kingsley AG, Christine LR, John Hl. (2008). Determinants of Neonatal Mortality In Indonesia. BMC Public Health, 8: 232.

Tristiyanti WF (2006). Faktor-faktor Yang Mempengaruhi Status Anemia Pada Ibu Hamil Di Kecamatan Ciampea Kabupaten Bogor Jawa Barat. Departemen Gizi Masyarakat dan Sumber Daya Keluarga, Fakultas Pertanian, Institut Pertanian Bogor.

Varney H. (2010). Buku Ajar Asuhan Kebidanan. Fakultas Kesehatan Masyarakat, Universitas Indonesia. Depok: Departemen Gizi dan Kesehatan Masyarakat.

WHO. (2015). WHA Global Nutrition Target 2025: Low Birth Weight Policy Brief. Diunduh dari www.who.int/nutrition/topics/globaltargetslowbirthweight_policybrief.pdf. 